\title{
A Species-Specific Polymerase Chain Reaction Assay for Rapid Detection of Phytophthora nicotianae in Irrigation Water
}

\author{
Ping Kong, Chuanxue Hong, Steven N. Jeffers, and Patricia A. Richardson
}

First, second, and fourth authors: Department of Plant Pathology, Physiology, and Weed Science, Virginia Polytechnic Institute and State University, Hampton Roads Agricultural Research and Extension Center, Virginia Beach 23455; and third author: Department of Plant Pathology and Physiology, Clemson University, Clemson, SC 29634. Accepted for publication 18 February 2003.

\begin{abstract}
Kong, P., Hong, C. X., Jeffers, S. N., and Richardson, P. A. 2003. A species-specific polymerase chain reaction assay for rapid detection of Phytophthora nicotianae in irrigation water. Phytopathology 93:822-831.

Phytophthora nicotianae is a common and destructive pathogen of numerous ornamental, agronomic, and horticultural crops such as tobacco, tomato, and citrus. We have developed a species-specific polymerase chain reaction (PCR) assay for rapid and accurate detection of this pathogen in irrigation water, a primary source of inoculum and an efficient means of propagule dissemination. This PCR assay consists of a pair of species-specific primers (PN), customization of a commercial soil DNA extraction kit for purification of DNA from propagules in irrigation water, and efficient PCR protocols for primer tests and sample detection.
\end{abstract}

ABSTRACT

The presence of Phytophthora nicotianae Breda de Haan (synonym Phytophthora parasitica Dastur) in irrigation water is well documented. This species has been isolated in nursery irrigation water in California (25), North Carolina (22), Oklahoma (39), and Virginia (13). It also was recovered from water sources used for irrigating citrus $(1,20,38,42)$, tobacco (5), and vegetable fields (36). Contaminated irrigation water can be a primary source of inoculum for Phytophthora diseases in nurseries (15). Plant pathogens such as $P$. nicotianae in nursery irrigation water are of increasing importance to ornamental crop producers recycling irrigation runoff to conserve water and prevent water contaminated with fertilizer and pesticides from leaving the nursery.

Infested irrigation water is not only an important source of inoculum, but also an efficient means of spreading pathogens from a single site of infection to an entire nursery, greenhouse, or farm and from one geographic location to other locations using the same water system $(28,31,38)$. Rapid, accurate, and sensitive detection is important for managing Phytophthora diseases and preventing pathogen spread. Standard isolation methods can take 1 to 2 weeks to process a water sample, which is inadequate for timely pest-management decisions. As a result, many nurseries chlorinate irrigation water continuously and apply fungicides routinely (C. $\mathrm{X}$. Hong and S. N. Jeffers, personal observations). Enzyme-linked immunosorbent assays (ELISA) and other serological methods offer potential as detection tools for irrigation water, but many questions must be resolved before these methods can be used effectively, and the results can be misinterpreted by growers $(2,26$, 40). False positive results with ELISA kits for Phytophthora spp. due to cross reaction with Pythium spp. have been reported (2).

Corresponding author: C. X. Hong; E-mail address: chhong2@vt.edu

Publication no. P-2003-0428-02R

(C) 2003 The American Phytopathological Society
The PN primers proved adequately specific for $P$. nicotianae in evaluations with 131 isolates of $P$. nicotianae, 102 isolates from 15 other species of Phytophthora, and 64 isolates from a variety of other oomycetes, true fungi, and bacteria. These isolates originated from a wide range of host plants, three substrates (plant tissue, soil, and irrigation water), and numerous geographic locations. The detection sensitivity is between 80 and $800 \mathrm{fg} \mathrm{DNA} / \mu \mathrm{l}$. The assay detected the pathogen in naturally infested water samples from Virginia and South Carolina nurseries more rapidly and accurately than standard isolation methods. Use of this PCR assay can assist growers in making timely disease management decisions with confidence.

Additional keywords: epidemiology, identification, population biology.

This is a major concern because the population of Pythium spp. can be greater than that of Phytophthora spp. in irrigation water $(2,13,34,40)$ and many of these species are weak or nonpathogens.

DNA-based techniques have become an effective means for identification of plant pathogens $(6,11,23,24)$. Because of advantages in speed, sensitivity, specificity, and flexibility, polymerase chain reaction (PCR) methods have been used extensively and offer great promise in future plant pathogen detection systems $(3,8,18,30,33,35,37)$. P. nicotianae-specific primers have been used for rapid identification of pure cultures (6) or detection of the pathogen in tobacco and tomato plants as well as in zoospore suspensions in the laboratory (21). The primer pair designed by Ersek et al. (6) was based on the sequence of a $P$. parasiticaspecific DNA probe that may contain a repetitive sequence unit (11), whereas the other pair was derived from a $P$. nicotianae elicitin gene, parAl (19). parAl is a good candidate for designing specific PCR primers due to its high copy number (19) and the specificity potential (21). But the sequence of parAl coding and noncoding regions recently has been found to share a high degree of similarity with those of elicitin genes of many other oomycetes including Pythium spp. (10,32). Cross reaction with other oomycetes is likely if the primers are located within homologous regions or if they were not tested thoroughly.

There has been little work on PCR detection of $P$. nicotianae in irrigation water. Irrigation water contains numerous microbes and residues of fertilizers and pesticides, which may cause cross reactions or reaction inhibition during molecular detection. Neither of the two pairs of primers $(6,21)$ has been tested with irrigation water samples. The detection specificity and sensitivity of these primers for irrigation water is unknown. In this study, we have developed a species-specific PCR assay for detection of P. nicotianae in irrigation water. Our specific objectives were to (i) design a pair of $P$. nicotianae-specific primers that provide the specificity and sensitivity required for irrigation water samples, (ii) find 
an effective method for purification of DNA from propagules of $P$. nicotianae in irrigation water, and (iii) develop efficient PCR protocols for evaluating the sensitivity and specificity of primers and sample detection.

\section{MATERIALS AND METHODS}

Fungi and bacteria. Isolates of Phytophthora spp., Pythium spp., other common water mold fungi, waterborne bacteria, and true fungi used in this study are listed in Tables 1, 2, and 3. A total of 131 isolates of P. nicotianae (Table 1) and 102 isolates of 15 other species of Phytophthora (Table 2) from a wide range of host plants and three substrates (plant tissue, soil, and irrigation water) in numerous geographic locations were tested. Also tested were 21 isolates of Pythium spp. and 12 isolates of true fungi from nine host plants in three states (Table 3) as well as 16 isolates of other common water mold fungi and 15 isolates of bacteria from recycled irrigation water in Virginia (Table 3).

Isolates of Phytophthora spp., Pythium spp., and other water mold fungi were grown on V8 juice agar (V8A) (9) in 6-cm-diameter petri dishes for 1 week at $20^{\circ} \mathrm{C}$ in the dark and maintained on V8A slants at $15^{\circ} \mathrm{C}$ in the dark. Isolates of true fungi and bacteria were grown on potato dextrose agar (PDA) in 10-cm-diameter petri dishes at $23^{\circ} \mathrm{C}$ in the dark for 2 weeks and 3 days, respectively, and maintained on PDA slants at $4^{\circ} \mathrm{C}$.

Zoospores used in this study were produced by an isolate (1B11) of $P$. nicotianae recovered from a diseased annual vinca
(Catharanthus roseus) plant. Zoospores were produced by incubating finely chopped mycelium plugs bearing numerous sporangia for 2 to $4 \mathrm{~h}$ (depending on the temperature) in $25 \mathrm{ml}$ of prechilled sterile soil water extract (SSWE) under fluorescent light. Zoospore suspensions were filtered through two layers of cheesecloth to remove mycelia and agar blocks; zoospores then were encysted by vortexing $1 \mathrm{ml}$ of the original suspension in a microcentrifuge tube for $1 \mathrm{~min}$ to facilitate counting. Zoospore concentrations initially were determined by using a hemacytometer on a light microscope at $\times 100$ and by plating zoospore suspensions on PARP-V8 agar (9) in 6-cm-diameter petri dishes. The results from the plating method confirmed those determined by direct enumeration on the microscope. Subsequently, the hemacytometer was used as a primary means for determining zoospore concentration.

Concentrations of initial suspensions were approximately $10^{4}$ zoospores $/ \mathrm{ml}$. To obtain higher concentrations of zoospores, 1 to $1.5 \mathrm{ml}$ of the original suspension was centrifuged in a $1.5-\mathrm{ml}$ microcentrifuge tube at $10,000 \times g$ for $1 \mathrm{~min}$, and the pellet was resuspended in a smaller volume of SSWE. To obtain lower concentrations, the original suspension was diluted as needed with sterile nanopure water (SDW), $10 \mathrm{mM}$ Tris-Cl, or irrigation water that had been passed through an Osmonics membrane filter with 5 - $\mu$ m pores (Osmonics Laboratory Products, Minnetonka, MN).

DNA extraction. DNA of pure cultures was extracted using a modified boiling method. For fungi, $2 \mathrm{~cm}^{2}$ of 1 - to 2-week-old mycelium were scraped from the surface of a culture on V8 agar and placed in a $1.5-\mathrm{ml}$ microcentrifuge tube containing $500 \mu \mathrm{l}$ of

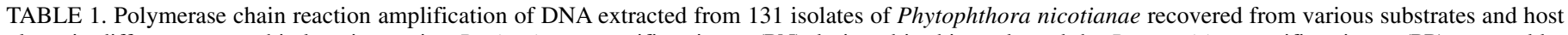

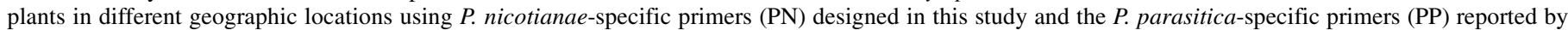
Ersek et al. (6)

\begin{tabular}{|c|c|c|c|c|c|}
\hline \multicolumn{2}{|c|}{ Isolate/origin } & \multirow[b]{2}{*}{ No. isolates tested } & \multicolumn{3}{|c|}{ Amplification detected } \\
\hline Host or substrate & Location $^{\mathrm{a}}$ & & PN & PP & Source $^{a}$ \\
\hline Abies sp. & West Virginia & 1 & 1 & 1 & 3 \\
\hline Antirrhinum majus & South Carolina (SC) & 2 & 2 & 2 & 6 \\
\hline Buxus sp. & SC, Virginia (VA) & 5 & 5 & 5 & 5,6 \\
\hline Catharanthus roseus & $\mathrm{SC}, \mathrm{VA}$ & 26 & 26 & 26 & 5,6 \\
\hline Ceratostigma plumbaginioides & $\mathrm{SC}$ & 1 & 1 & 1 & 6 \\
\hline Chamaerops humilis & $\mathrm{SC}$ & 1 & 1 & 1 & 6 \\
\hline Chionanthus retusus & $\mathrm{SC}$ & 1 & 1 & 1 & 6 \\
\hline Citrus limon & California (CA) & 1 & 1 & 1 & 3 \\
\hline Citrus spp. & CA, India & 7 & 7 & 7 & 1,3 \\
\hline Daphne spp. & $\mathrm{SC}, \mathrm{VA}$ & 21 & 21 & 21 & 5,6 \\
\hline Delosperma nubigenum & $\mathrm{SC}$ & 1 & 1 & 1 & 6 \\
\hline Fatsia japonica & $\mathrm{SC}$ & 3 & 3 & 2 & 6 \\
\hline Forsythia sp. & $\mathrm{SC}$ & 1 & 1 & 1 & 6 \\
\hline Gaura lindheimeri & $\mathrm{SC}$ & 1 & 1 & 1 & 6 \\
\hline Hedera spp. & $\mathrm{SC}$ & 12 & 11 & 10 & 6 \\
\hline Hemerocallis sp. & $\mathrm{SC}$ & 1 & 1 & 1 & 6 \\
\hline Juniperus sp. & $\mathrm{SC}$ & 1 & 1 & 1 & 6 \\
\hline Kniphofia hybrid & $\mathrm{SC}$ & 1 & 1 & 1 & 6 \\
\hline Ligustrum sp. & $\mathrm{SC}$ & 1 & 1 & 1 & 6 \\
\hline Ilex crenata & $\mathrm{SC}$ & 1 & 1 & 1 & 6 \\
\hline Michelia figo & $\mathrm{SC}$ & 1 & 1 & 1 & 6 \\
\hline Nicotiana tabacum & North Carolina (NC) & 3 & 3 & 3 & 3 \\
\hline Penstemon sp. & $\mathrm{SC}$ & 1 & 1 & 1 & 6 \\
\hline Petunia sp. & $\mathrm{SC}$ & 2 & 2 & 2 & 6 \\
\hline Phlox paniculata & $\mathrm{SC}$ & 1 & 1 & 1 & 6 \\
\hline Pinckneya pubens & $\mathrm{SC}$ & 1 & 1 & 0 & 6 \\
\hline Rhododendron sp. & VA & 1 & 1 & 1 & 4 \\
\hline Salvia sp. & $\mathrm{SC}$ & 1 & 1 & 1 & 6 \\
\hline Solanum tuberosum & $\mathrm{NC}$ & 1 & 1 & 1 & 3 \\
\hline Verbena sp. & $\mathrm{SC}$ & 2 & 2 & 2 & 6 \\
\hline Vinca minor & $\mathrm{NC}, \mathrm{SC}$ & 8 & 8 & 7 & 2,6 \\
\hline Viola $\times$ wittrockiana & $\mathrm{SC}$ & 1 & 1 & 1 & 6 \\
\hline Nursery irrigation water & Oklahoma, SC, VA & 12 & 12 & 12 & $5,6,7$ \\
\hline Tester & VA & 2 & 2 & 2 & 4 \\
\hline$\ldots{ }^{b}$ & $\ldots{ }^{b}$ & 5 & 5 & 5 & 3 \\
\hline
\end{tabular}

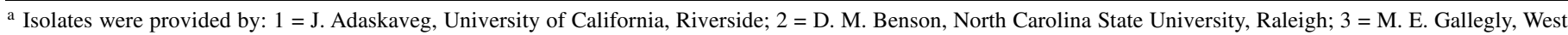

Virginia University, Morgantown; 4= M. A. Hansen, Virginia Tech, Blacksburg; $5=$ C. Hong, Virginia Tech, Virginia Beach; $6=$ S. N. Jeffers, Clemson University, Clemson, SC; and 7 = S. L. von Broembsen, Oklahoma State University, Stillwater.

b... = Not known. 
$10 \mathrm{mM}$ Tris- $\mathrm{HCl}$ ( $\mathrm{pH}$ 7.5). DNA was released by boiling mycelia in a heat block for $20 \mathrm{~min}$ and vortexing for $3 \mathrm{~min}$. Similarly, individual colonies of bacteria on PDA were harvested and boiled in $100 \mu \mathrm{l}$ of the same buffer. The supernatants (containing raw DNA) were used immediately or stored at $-20^{\circ} \mathrm{C}$ until further use. DNA of $P$. nicotianae isolate $1 \mathrm{~B} 11$ also was purified using the DNeasy Plant Maxi Kits (Qiagen Inc, Valencia, CA) following the manufacturer's instructions.

DNA of organisms artificially and naturally present in water was extracted using the UltraClean Soil DNA Kit (MO BIO Laboratories, Inc., Solana Beach, CA). Propagules were collected by filtration or centrifugation prior to DNA extraction. For filtration, a predetermined volume of zoospore suspension or naturally infested irrigation water was passed through a 47-mm-diameter nylon membrane filter with 5 - $\mu$ m pores using a vacuum pressure of $5.53 \mathrm{~Pa}(41.5 \mathrm{~cm} \mathrm{Hg})$, which captured propagules on the filter. For centrifugation, zoospore suspensions or irrigation water were centrifuged (Sorvall RC 5D Plus centrifuge; Kendro Laboratory Products, Newtown, CT) at $10,000 \times g$ for $10 \mathrm{~min}$ to pellet the propagules. DNA was extracted from propagules on filters or in pellets using the UltraClean Soil DNA Kit with some modifications to the first step. Briefly before starting extraction, the filter was cut into fine pieces while wet, and these pieces were placed into the bead tube (included in the kit for loading a soil sample). Alternatively, the propagule pellet was resuspended with the solution from the bead tube and was poured back into the tube. The remaining extraction steps followed the manufacturer's instructions. Extracted DNA was eluted with $100 \mu \mathrm{l}$ of SDW unless otherwise stated.

Primers and DNA amplification. A pair of Phytophthora nicotianae-specific primers, referred to as the PN primers, was designed based on specific sequences in the elicitin gene parAl (19) (GenBank Accession No. S67432) of the pathogen. The sequences of the forward primer (CCACCACGCAGCAAACTGCGGC) and the reverse primer (TTGAGTACCAGGCCGCTCGTAG) are located at nucleotides 70 to 91 and 287 to 308 of parA1, respectively. The specific sequences for the primers were determined by a BLAST search at the NCBI web site and by comparisons of parAl with elicitin genes of other oomycetes. Another primer pair reported previously by Ersek et al. (6) as specific to P. parasitica was used in this study for comparison and will be referred to as the PP primers. An additional primer pair, ITS6 and ITS7 (4), was used to assess the quality of DNA preparations from Oomycete isolates. All primers were synthesized at Sigma Genosys (Woodlands, TX).

PCR reactions were performed in a total volume of $25 \mu$ and each contained $2 \mu \mathrm{l}$ of boiled mycelium extract or DNA extract

TABLE 2. Polymerase chain reaction amplification using Phytophthora nicotianae-specific primers designed in this study of DNA extracted from 102 isolates of 15 other species of Phytophthora recovered from various substrates and host plants in different geographic locations

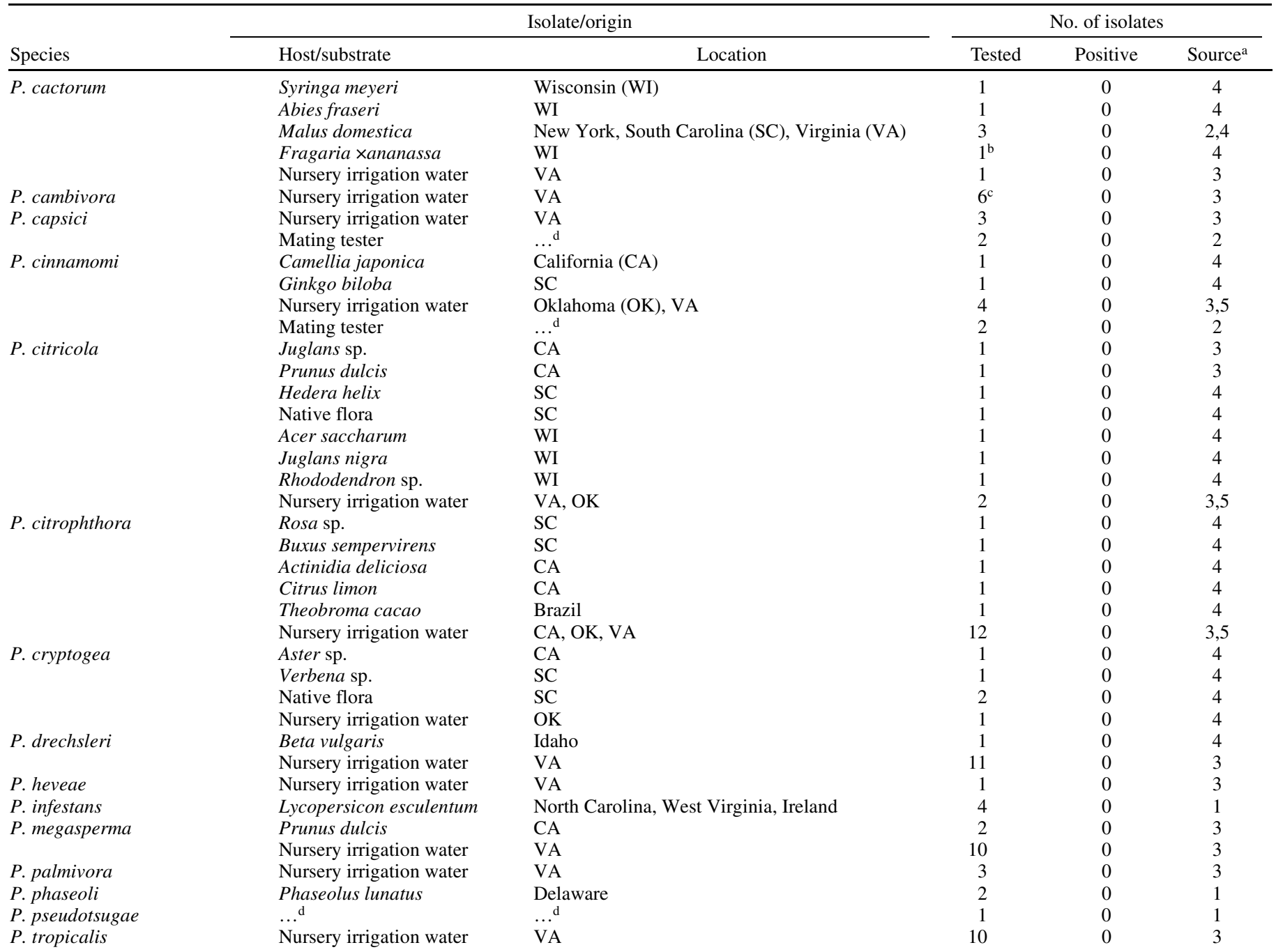

${ }^{a}$ Isolates were provided by: 1 = M. E. Gallegly, West Virginia University, Morgantown; 2 = M. A. Hansen, Virginia Tech, Blacksburg; $3=$ C. Hong, Virginia

Tech, Virginia Beach; 4 = S. N. Jeffers, Clemson University, Clemson, SC; and 5 = S. L. von Broembsen, Oklahoma State University, Stillwater.

${ }^{\mathrm{b}}$ The isolate produced an amplicon slightly larger than the specific one.

c One isolate produced an amplicon discernibly higher than the specific one.

$\mathrm{d} \ldots=$ Not known. 
using the UltraClean Soil DNA Kit, unless otherwise stated. Each reaction used $2.5 \mu \mathrm{l}$ of the $10 \times$ PCR buffer, $2.5 \mu \mathrm{l}$ of each of the $10 \mu \mathrm{M}$ primer solutions, $2 \mu \mathrm{l}$ of the $2 \mathrm{mM}$ dNTP solutions, $0.1 \mu \mathrm{l}$ (5 U/ul) of Taq polymerase (TaKaRa, Shuzo Co. Ltd., Kyoto, Japan), and 13.4 $\mu \mathrm{l}$ of SDW. PCR was carried out in a PerkinElmer 480 thermal cycler with initial denaturation at $96^{\circ} \mathrm{C}$ for $2 \mathrm{~min}$, followed by 40 cycles of $94^{\circ} \mathrm{C}$ for $30 \mathrm{~s}, 65^{\circ} \mathrm{C}$ for $45 \mathrm{~s}$, $72^{\circ} \mathrm{C}$ for $1 \mathrm{~min}$, and a final extension at $72^{\circ} \mathrm{C}$ for $10 \mathrm{~min}$. Alternatively, $10 \mu \mathrm{l}$ of a known number of zoospores in a suspension was added to a PCR reaction (i.e., zoospore PCR), following the above procedure without additional SDW. An extended initial denaturing time of 3 min was added to the PCR program.

PCR with either the PN or PP primer pair always included a positive control with purified DNA from $P$. nicotianae and a negative control with SDW. An aliquot of $5 \mu \mathrm{l}$ of PCR products from each sample was resolved by electrophoresis in 1.0 to $1.5 \%$ agarose or $3 \%$ Nusieve gels stained with ethidium bromide. Images were captured and analyzed using a BioImaging Chemi System (UVP, Inc., Upland, CA).

DNA hybridization assays. Detection of $P$. nicotianae was verified by DNA hybridization. Five microliters of the PCR products were used for electrophoresis in a 3\% Nusieve gel, and following denaturing and neutralization, the gel was blotted on an ImmobilonNy+ transfer membrane (Millipore Corporation, Bedford, MA). The blot was probed with digoxigenin (DIG)-labeled parAl gene of $P$. nicotianae using the PCR DIG Probe Synthesis
Kit, and DNA was detected using the DIG Luminescent Detection Kit following the manufacturer's instructions (Roche Diagnostics $\mathrm{GmbH}$, Indianapolis, IN). Images were captured and analyzed using the BioImaging Chemi System.

Specificity and sensitivity tests. The specificity of the PN primers was compared with that of the PP primers using raw DNA from 131 isolates of P. nicotianae (Table 1). The specificity of the PN primers also was evaluated using raw DNA from 166 isolates of other oomycetes, fungi, and bacteria (Tables 2 and 3).

The sensitivities of the PN and PP primers were compared using the zoospore-PCR procedure described above. An original suspension of $8 \times 10^{4}$ zoospores per ml was diluted to $10^{4}, 10^{3}$, and 100 zoospores per $\mathrm{ml}$ with SDW, $10 \mathrm{mM}$ Tris- $\mathrm{HCl}$, or irriation water filtrate. The original spore suspension or one of the dilutions was added directly to a PCR reaction.

The sensitivity of the PN primers was further compared among five isolates of $P$. nicotianae. These isolates originated from different hosts and geographic locations: 1B11 from Catharanthus roseus in North Carolina, 1E2 from nursery irrigation water in Oklahoma, 21J1from Citrus sp. in California, 23B5 from Abies fraseri in West Virginia, and 23B8 from Citrus sp. in India. For each isolate, zoospores were produced as described previously, but DNA was extracted using the UltraClean Soil DNA kit by direct addition of $100 \mu \mathrm{l}$ of suspension containing 1,000 zoospores to the bead tube; extracted DNA was eluted in $50 \mu \mathrm{l}$ of SDW. Serial dilutions (up to $10^{-5}$ ) of these DNA extracts were

TABLE 3. Polymerase chain reaction amplification using Phytophthora nicotianae-specific primers designed in this study of DNA extracted from various microorganisms commonly encountered in irrigation water and nursery production

\begin{tabular}{|c|c|c|c|c|c|}
\hline \multirow[b]{2}{*}{ Microorganism } & \multicolumn{2}{|c|}{ Isolate/origin } & \multicolumn{3}{|c|}{ No. of isolates } \\
\hline & Host/substrate & State & Tested & Positive & Source $^{a}$ \\
\hline \multirow[t]{2}{*}{ Pythium aphanidermatum } & Chrysanthemum sp. & Pennsylvania (PA) & 1 & 0 & 2 \\
\hline & Euphorbia sp. & PA & 1 & 0 & 2 \\
\hline \multirow[t]{2}{*}{ Pythium irregulare } & Pelargonium sp. & $\mathrm{PA}$ & $1^{\mathrm{b}}$ & 0 & 2 \\
\hline & Euphorbia sp. & PA & 1 & 0 & 2 \\
\hline Pythium myriotylum & Pelargonium sp. & PA & 2 & 0 & 2 \\
\hline \multirow[t]{3}{*}{ Pythium ultimum } & Seedling & California (CA) & 1 & 0 & 1 \\
\hline & Pelargonium sp. & PA & 1 & 0 & 2 \\
\hline & Euphorbia sp. & PA & 1 & 0 & 2 \\
\hline Pythium spp. ${ }^{\mathrm{c}}$ & Nursery irrigation water & Virginia (VA) & 12 & 0 & 1 \\
\hline Allomyces sp. ${ }^{\mathrm{d}}$ & Nursery irrigation water & $\mathrm{VA}$ & 1 & 0 & 1 \\
\hline Mortierella spp. ${ }^{\mathrm{d}}$ & Nursery irrigation water & VA & 2 & 0 & 1 \\
\hline Saprolegnia mixta ${ }^{\mathrm{d}}$ & Nursery irrigation water & VA & 2 & 0 & 1 \\
\hline Saprolegnia spp. ${ }^{\mathrm{d}}$ & Nursery irrigation water & VA & 5 & 0 & 1 \\
\hline Thraustotheca sp. $^{\mathrm{d}}$ & Nursery irrigation water & VA & 1 & 0 & 1 \\
\hline Chytrids $^{\mathrm{d}}$ & Nursery irrigation water & VA & 2 & 0 & 1 \\
\hline Unknown water molds & Nursery irrigation water & VA & 3 & 0 & 1 \\
\hline Bacterium/grey & Nursery irrigation water & VA & 3 & 0 & 1 \\
\hline Bacterium/yellow & Nursery irrigation water & VA & 3 & 0 & 1 \\
\hline Bacterium/milky & Nursery irrigation water & VA & 3 & 0 & 1 \\
\hline Bacterium/white large & Nursery irrigation water & VA & 3 & 0 & 1 \\
\hline Bacterium/white small & Nursery irrigation water & VA & $3^{f}$ & 0 & 1 \\
\hline Alternaria alternata & Daucus carota & $\mathrm{CA}$ & 1 & 0 & 1 \\
\hline Alternaria daucia & Daucus carota & $\mathrm{CA}$ & 1 & 0 & 1 \\
\hline Alternaria microspora & Daucus carota & $\mathrm{CA}$ & 1 & 0 & 1 \\
\hline Alternaria porri & Daucus carota & $\mathrm{CA}$ & $1^{\mathrm{g}}$ & 0 & 1 \\
\hline Alternaria radicina & Daucus carota & $\mathrm{CA}$ & 1 & 0 & 1 \\
\hline Alternaria solani & Daucus carota & $\mathrm{CA}$ & 1 & 0 & 1 \\
\hline Botrytis cinerea & Prunus persica & $\mathrm{CA}$ & 1 & 0 & 1 \\
\hline Monilinia fructicola & Prunus persica & $\mathrm{CA}$ & 1 & 0 & 1 \\
\hline Monilinia laxa & Prunus persica & $\mathrm{CA}$ & 1 & 0 & 1 \\
\hline Rhizoctonia sp. & Rhododendron sp. & VA & 1 & 0 & 1 \\
\hline Thielaviopsis sp. & Viola tricolor & VA & 1 & 0 & 1 \\
\hline Ulocladium sp. & Daucus carota & $\mathrm{CA}$ & 1 & 0 & 1 \\
\hline
\end{tabular}

${ }^{a}$ Isolates were provided by: 1 = C. Hong, Virginia Tech, Virginia Beach; and 2 = G. W. Moorman, Pennsylvania State University, University Park.

${ }^{\mathrm{b}}$ The isolate produced a faint and significantly higher molecular weight band than the specific one.

${ }^{\mathrm{c}}$ Representing the major groups of Pythium spp. isolated from irrigation runoff and irrigation water at two nurseries during monthly samplings in $2000-2001$ and at four additional nurseries during quarterly samplings in 2000 .

d Tentative identification.

${ }^{\mathrm{e}}$ Color of bacterium colonies; no identification of bacteria was attempted.

${ }^{\mathrm{f}}$ One isolate produced a slightly lower molecular weight amplicon than the specific one.

$\mathrm{g}$ The isolate produced a faint and higher molecular weight band than the specific one. 
prepared with SDW and used in PCR reactions along with the original extract.

The sensitivity of the PN primers also was compared using two zoospore-collecting methods and six zoospore quantities. The two methods were filtration and centrifugation, and the six quantities were $2 \times 10^{5}, 2 \times 10^{4}, 2 \times 10^{3}, 200,20$, and 2 zoospores in $100 \mathrm{ml}$ of SSWE for filtration method and in $40 \mathrm{ml}$ of SSWE for centrifugation. DNA was extracted from a filter or pellet after zoospores were collected from a suspension as described above, and extracted DNA was eluted with $50 \mu \mathrm{l}$ of SDW.

Another experiment was conducted to investigate the effect of DNA quality on template amplification. Two DNA extraction samples, one from irrigation runoff water and the other from irrigation pond water, previously had tested negative with the PN primers. These DNA extraction samples were compared with SDW by adding purified DNA of $P$. nicotianae isolate $1 \mathrm{~B} 11$ at various concentrations starting at $1 \mu \mathrm{g} / \mu \mathrm{l}$. One microliter of the original or diluted purified DNA was mixed with $9 \mu \mathrm{l}$ of DNA extracted from irrigation runoff water or irrigation pond water to make six final template concentrations of $8 \mathrm{ng} / \mu \mathrm{l}, 800,80$, and $8 \mathrm{pg} / \mu \mathrm{l}$, and 800 and $80 \mathrm{fg} / \mu \mathrm{l}$ in PCR reaction mixes. Another set was prepared with SDW only. The two extraction samples and SDW with or without addition of purified DNA of P. nicotianae were subjected to PCR with the PN primers. All tests above were repeated.

Detection of $\boldsymbol{P}$. nicotianae in irrigation water. The PCR assay developed in this study was compared with the protocol of Ersek et al. (6) as well as standard isolation methods $(1,16)$ using naturally infested irrigation water collected at commercial nurseries in Virginia and South Carolina. In Virginia, three replicate samples of each of irrigation runoff and irrigation water were collected in 3.8-liter plastic bottles at points where runoff entered a retention pond or at irrigation risers in the nursery from May to September 2001. The samples were transported in a cooled ice

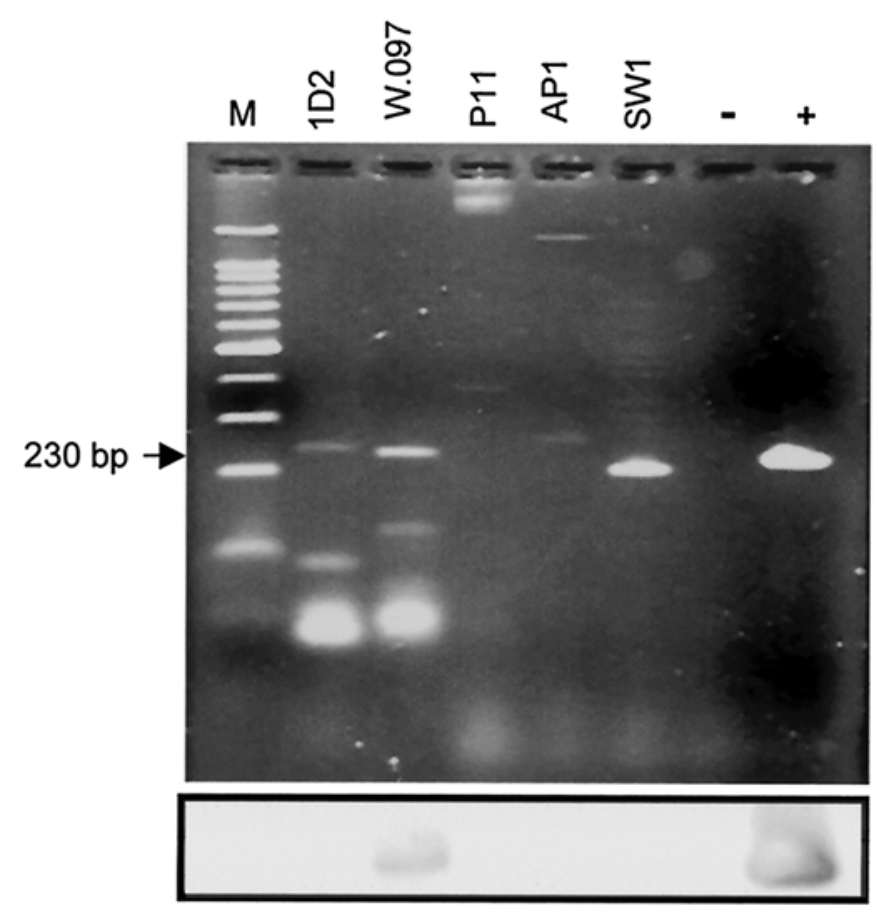

Fig. 1. Three percent Nusieve gel electrophoresis of polymerase chain reaction (PCR) products of test species that were similar to the specific band of the Phytophthora nicotianae-specific primers designed in this study (top); DNA hybridization of the PCR products with the parAl probe (bottom). $\mathrm{M}=$ 100-bp DNA ladder; 1D2 $=P$. cambivora from irrigation water; W.097 $=P$. cactorum from Fragaria $\times$ ananassa $;$ P11 = Pythium irregulare from Pelargonium; $\mathrm{AP} 1=$ Alternaria porri from Daucus carota , SW1 = bacterium from irrigation water; $-=$ Negative control with sterile nanopure water; $+=$ positive control with purified DNA from $P$. nicotianae. chest to the laboratory in Virginia Beach, VA, where they were assayed by filter-based isolation and the PCR method. Samples were assayed by filter-based isolation following the protocol described previously $(16,25)$. Briefly, three aliquots of $50 \mathrm{ml}$ of runoff water or $100 \mathrm{ml}$ of irrigation water were taken from each replicate bottle and passed through a 47-mm-diameter Durapore membrane filter with $5-\mu \mathrm{m}$ pores (Millipore Corporation). Propagules captured on each filter were resuspended in $6 \mathrm{ml}$ of $0.09 \%$ sterile water agar in a test tube. A 100- $\mu$ l aliquot of resultant suspension was spread over PARP-V8 agar in each of two $10-\mathrm{cm}-$ diameter petri dishes. Isolation dishes were incubated at $23^{\circ} \mathrm{C}$ in the dark for up to 7 days, and colonies were counted daily after 2 days. Twenty percent of representative colonies were subcultured and identified based on morphological characters $(7,41)$.

In South Carolina, duplicate water samples ( 0.5 or 1 liter) were collected during September 2001 from three irrigation ponds at two commercial nurseries ( $\mathrm{G}$ and $\mathrm{S}$ ) and from a stream running through a landscaped area (CU). One set of samples was assayed by filter-based isolation at Clemson University and one set of samples was sent by overnight courier to Virginia Beach to be assayed by the PCR method. For filter-based isolation, five replicate aliquots of water ( 75 to $200 \mathrm{ml}$, depending on the sample) were used for each sample; each aliquot was passed through a 47-mm-diameter Nucleopore polycarbonate membrane filter with 3- $\mu$ m pores (Whatman, Inc., Clifton, NJ). Each filter was inverted onto a petri dish containing PARPH-V8 agar (9). Isolation dishes were incubated at $20^{\circ} \mathrm{C}$ in the dark for 3 days. Filters were removed, the agar surface was rinsed under running tap water and colonies were counted. Petri dishes were incubated for four more days at $20^{\circ} \mathrm{C}$ and checked for additional colonies. Representative colonies from each dish were subcultured and identified.

All PCR detection was performed in the laboratory at Virginia Tech in Virginia Beach, VA, using the PN or PP primers. Water
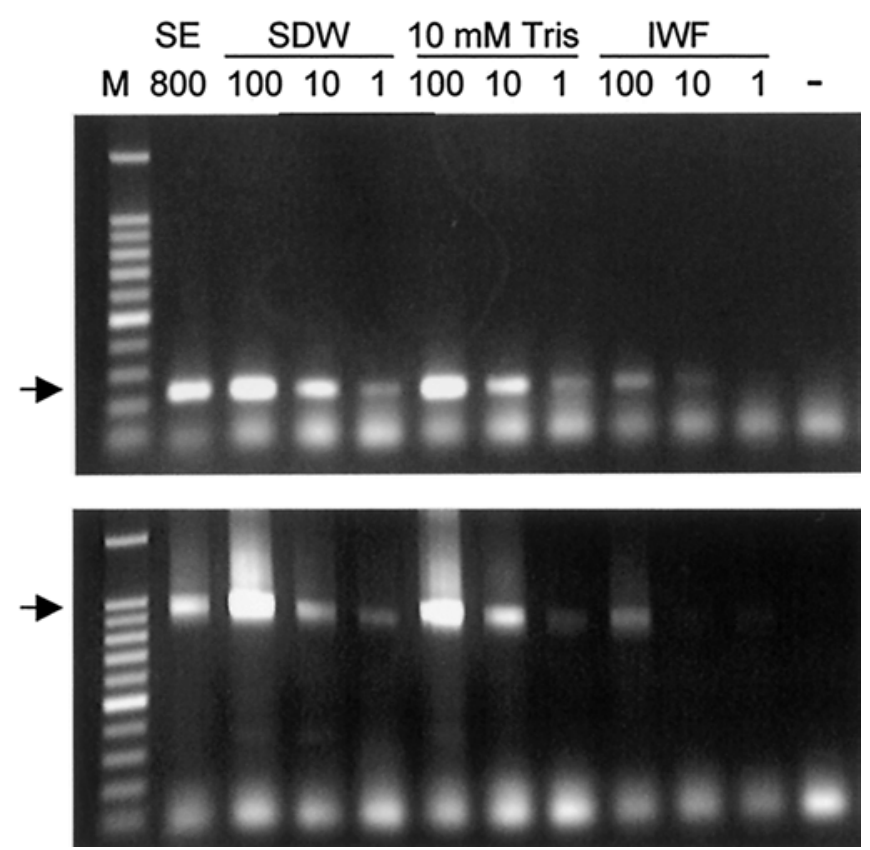

Fig. 2. Agarose gel electrophoresis of the polymerase chain reaction (PCR) products obtained from suspensions of Phytophthora nicotianae at $8 \times$ $10^{4}$ zoospores per $\mathrm{ml}$ to $10^{4}, 10^{3}$ and $10^{2}$ zoospores per $\mathrm{ml}$. The initial zoospore suspension was prepared with soil water extract (SE) and diluted with sterile distilled water (SDW), $10 \mathrm{mM}$ Tris-Cl, or irrigation water filtrate (IWF; i.e., water that had been passed through an Osmonics nylon membrane filter with 5- $\mu \mathrm{m}$ pores). The number of zoospores added to a PCR reaction is listed above each lane. $M=100$-bp DNA ladder; $-=$ negative control with SDW only. Sizes of the specific bands for the P. nicotianae-specific primers designed in this study (top) and the $P$. parasitica-specific primers designed by Ersek et al. (6) (bottom) are indicated by arrows. 
samples from Virginia were assayed on the day of sampling. Three 500-ml bottles of water from each sample location in South Carolina were assayed upon their arrival. From each replicate bottle from Virginia or South Carolina, $50 \mathrm{ml}$ (runoff) or $100 \mathrm{ml}$ (pond and stream) of water was used. Pathogen propagules were collected using the filtration method, and DNA was extracted using the UltraClean Soil DNA purification kit as described previously. DNA at original concentration was used for Virginia water samples, while DNA at both original and $5 \times$ concentration was used for South Carolina water samples. The original DNA extract was concentrated with an ethanol precipitation procedure described by the kit manufacturer, followed by resuspending the DNA in $20 \mu \mathrm{l}$ of SDW. PCR products from all water samples were electrophoresed on 3\% Nusieve gels and the detection results were verified by DNA hybridization with the parAl probe to identify false detection.

\section{RESULTS}

Primers and DNA amplification. All DNA preparations from oomycetes were amplified with the ITS6 and ITS7 primers, resulting in an amplicon at ca. $300 \mathrm{bp}$, demonstrating that they were of sufficient quality as PCR templates. The PCR using the PN primers with purified DNA of $P$. nicotianae produced an amplicon at $230 \mathrm{bp}$, whereas the PP primers produced one at $950 \mathrm{bp}$.

Specificity. The PN primers allowed greater detection of $P$. nicotianae isolates than the PP primers (Table 1). Of the 131 isolates tested, the PN primers detected 130 isolates and the PP primers detected 126 isolates; the PN primers did not detect one isolate from Hedera helix, while the PP primers failed to detect five isolates from Fatsia japonica, Hedera spp., Pinckneya pubens and Vinca minor.

The PN primers were specific when they were evaluated with 102 isolates from 15 other species of Phytophthora (Table 2). Only one of seven isolates of P. cactorum (W.097) and one of six isolates of $P$. cambivora (1D2) gave an amplification. These two amplicons were discernibly higher than the one from the positive control with the amplicon from isolate W.097 closer to the 230-bp target band on a $3 \%$ Nusieve gel (Fig. 1). Amplicons of the $P$. cambivora isolate did not hybridize with the parAl probe of $P$. nicotianae, but those from the $P$. cactorum isolate did hybridize with the parAl probe (Fig. 1).

The PN primers also were specific when tested with 64 isolates of bacteria and fungi from other genera. With two exceptions, DNA from all isolates of Pythium spp. and true fungi was not amplified by the PN primers (Table 3). Two faint bands each associated with an isolate of Pythium irregulare (P11) or Alter-

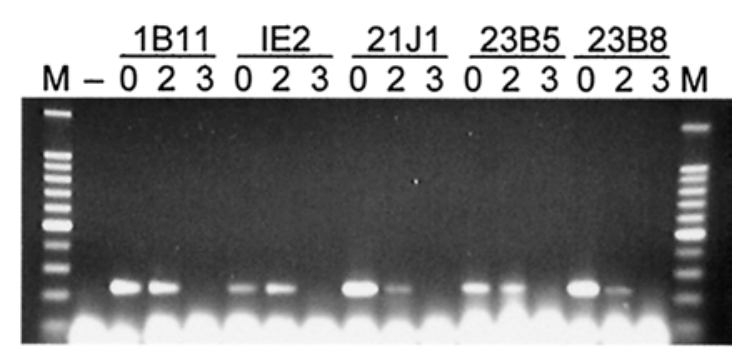

Fig. 3. Agarose gel electrophoresis of polymerase chain reaction (PCR) products using the Phytophthora nicotianae-specific primers designed in this study with DNA from five isolates of $P$. nicotianae with different origins: 1B11 from Catharanthus roseus in North Carolina; 1E2 from nursery irrigation water in Oklahoma; 21J1from Citrus sp. in California; 23B5 from Abies fraseri in West Virginia; and 23B8 from Citrus sp. in India. For each isolate, DNA was extracted from 1,000 zoospores using the UltraClean Soil DNA extraction kit. Original DNA extract $(0)$ and $10^{-2}(2)$ and $10^{-3}$ dilutions (3) were used for template amplification. $-=$ Negative control with sterile nanopure water; $\mathrm{M}=100$-bp DNA ladder. naria porri (AP1) were larger than the target band (230 bp) and easy to discriminate (Fig. 1). All other water mold fungi tested negative with the PN primers. Only one of the 15 isolates of bacteria tested had a fragment with size slightly smaller than $230 \mathrm{bp}$, and this was negative in the DNA hybridization assay (Fig. 1 and Table 3).

Sensitivity. The PN primers were more sensitive than the PP primers (Fig. 2). The zoospore PCR with the PN primers detected $P$. nicotianae at levels of one zoospore in SDW or in $10 \mathrm{mM}$ Tris$\mathrm{HCl}$ solution and 10 zoospores in pond water filtrate. The PP primers detected $P$. nicotianae at one zoospore in SDW or in Tris$\mathrm{HCl}$ with a weaker signal than that detected by the PN primers, and they needed at least 100 zoospores in irrigation water filtrate for positive detection.

The PN primers appeared to be equally sensitive to all five isolates of $P$. nicotianae tested (Fig. 3). The PCR produced positive results for all isolates at three concentrations of DNA extractincluding the $10^{-1}$ dilutions (data not shown). The positive signal was strong when original DNA extract was used but weakened with decreasing concentration of DNA templates. At the $10^{-2}$ dilution of DNA extract, the specific band differed slightly in intensity among the isolates.

Centrifugation was more effective than filtration at collecting zoospores for DNA extraction and detection under the test conditions (Fig. 4). PCR with the PN primers yielded positive results for all six concentrations from $2 \times 10^{5}$ to 2 zoospores per sample when centrifugation was used to collect the spores from water samples. In contrast, the PCR assay needed a minimum of 20 zoospores per sample for a positive signal when filtration was used. The sensitivity of the PCR assay was equivalent to 0.08 zoospores per reaction for the centrifugation method and 0.8 zoospores per reaction for filtration.

Addition of the purified DNA to both extraction samples from irrigation runoff water and irrigation pond water resulted in positive signals at the same levels as that added to SDW (Fig. 5). The intensity of the specific band appeared similar among the extraction samples and SDW and decreased with decreasing amount of the purified DNA. The PCR assay produced a positive signal at $800 \mathrm{fg} / \mu \mathrm{l}$ but not at $80 \mathrm{fg} / \mu \mathrm{l}$ for both extraction samples and SDW.

Detection of $P$. nicotianae in irrigation water. Using the PCR assay, $P$. nicotianae was detected in three of the five irrigation runoff samples (June, August, and September) and in one irrigation water sample (September) collected at the Virginia nurseries (Fig. 6). Hybridization of the PCR products with the $P$. nicotianae-specific probe derived from parAl confirmed all detection results. In contrast, the pathogen was detected with the PP primers

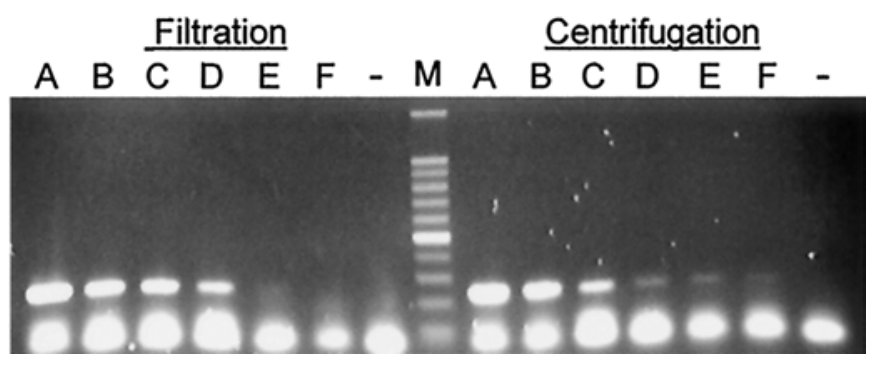

Fig. 4. Agarose gel electrophoresis of polymerase chain reaction products obtained with Phytophthora nicotianae-specific primers designed in this study using filtration or centrifugation to collect zoospores of P. nicotianae in sterile soil water extract. A $100-\mathrm{ml}$ aliquot of suspension containing $2 \times$ $10^{5}(\mathrm{~A}), 2 \times 10^{4}(\mathrm{~B}), 2 \times 10^{3}$ (C), 200 (D), 20 (E), or 2 zoospores (F) was passed through an Osmonics nylon membrane filter with 5 - $\mu$ m pores or a 40-ml aliquot of suspension containing the same numbers of zoospores was centrifuged at $10,000 \times g$ for $10 \mathrm{~min}$. DNA was extracted from the zoospores collected on the filters or in the pellets using the UltraClean Soil DNA extraction kit and eluted in $50 \mu$ of sterile distilled water. $-=$ negative control with sterile nanopure water; $\mathrm{M}=100$-bp DNA ladder. 
in two samples of runoff water (June and August) but not in any sample of irrigation pond water. Filter-based isolation only detected $P$. nicotianae in one runoff sample (August); zoospore concentrations were estimated to be 450 to $570 \mathrm{CFU} /$ liter.

$P$. nicotianae was detected in the irrigation water samples from two (G1 and CU) of the four locations in South Carolina when original DNA extracts were used (Fig. 6). The pathogen also was detected in the water samples collected from one other location (G2) when the $5 \times$ concentrated DNA extract was used (Fig. 6). Like the Virginia samples, DNA hybridization confirmed all PCR detection results of water samples from South Carolina. In contrast, the PP primers only detected the pathogen from the CU location using the original DNA extract but not using the $5 \times$ concentrated one. Filter-based isolation detected $P$. nicotianae in only one (CU) of the four South Carolina locations; zoospore concentration was estimated to be $65 \mathrm{CFU} /$ liter.

\section{DISCUSSION}

Rapid and reliable detection of pathogens is important for formulating strategies for disease management in nurseries. This study describes such a detection assay for $P$. nicotianae by using species-specific PCR. P. nicotianae is an economically important pathogen on numerous ornamental crops as well as many other crops, e.g., citrus, tomato, and tobacco (7). The PCR assay targeted this pathogen in irrigation water, which can be a primary source of inoculum at ornamental crop nurseries (15).

The PCR assay provided more rapid detection of $P$. nicotianae than standard filter-based isolation methods. The standard isolation methods are tedious and time-consuming and require considerable expertise to differentiate species of Phytophthora based on morphology, which can be difficult due to intraspecific variation and the overlap of morphological characters among species $(7,41)$. It takes at least a week to confirm $P$. nicotianae detection using standard isolation methods, which can delay disease-management decisions. In contract, the PCR assay developed in this study can provide definitive diagnosis within a few hours; it is easy to use and requires minimal training.

The PCR assay has adequate specificity for detection of $P$. nicotianae in irrigation water. The $\mathrm{PN}$ primers detected more isolates of $P$. nicotianae than the previously described (6) PP primers. This indicates the ability of our PCR assay to detect the pathogen from more diverse origins with a lower risk of producing false negatives. In addition, the PN primers had only insignificant cross reactions (actually unspecific amplifications) among a large number of diverse microorganisms. These results were not unexpected because the sequences of the PN primers have a low

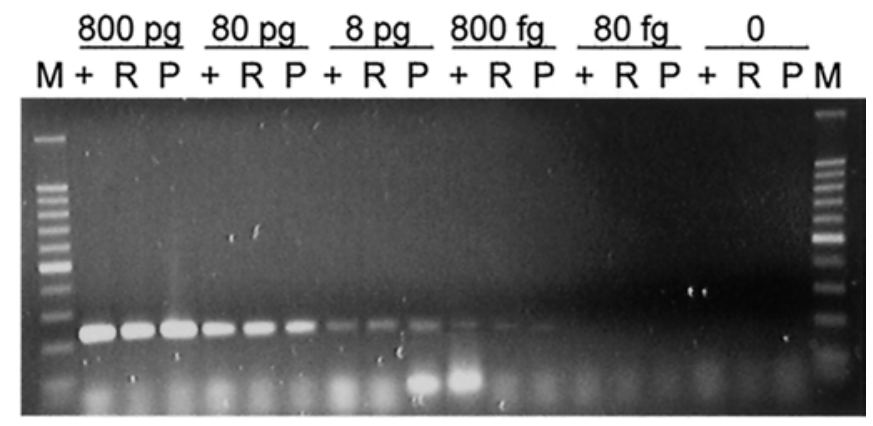

Fig. 5. Agarose gel electrophoresis of polymerase chain reaction (PCR) products using the Phytophthora nicotianae-specific primers designed in this study: $+=$ purified DNA of $P$. nicotianae that was added to and diluted in sterile nanopure water; $\mathrm{R}=\mathrm{DNA}$ extracted from an irrigation runoff water sample; and $\mathrm{P}=$ DNA extracted from an irrigation pond water sample. The runoff and pond water samples previously tested negative with the Phytophthora nicotianae-specific primers. The final template concentrations $(/ \mu \mathrm{l})$ in PCR reaction mixes are indicated above the lanes. $M=100$-bp DNA ladder. similarity with those of the elicitins of other oomycetes. The BLAST hits included 11 isolates from five species of Phytophthora with the majority having an E-value $\geq 6$ (data not shown). High guanine-cytosiene (GC) contents (68.18 and 59.09\%) and melting temperatures $\left(79.3\right.$ and $\left.69.3^{\circ} \mathrm{C}\right)$ of the forward and reverse primers also may have facilitated specific binding to complementary target sequences.

Specificity is essential for detecting $P$. nicotianae in irrigation water. Irrigation water is a complex ecosystem whose microbial community is diverse. For example, at least seven species of Phytophthora were recovered from nursery effluents in California (25) and five species recovered in Oklahoma (39). Similarly, 10 species of Phytophthora were recovered from nursery irrigation water in Virginia over the past 2 years (13) and at least five species have been found in South Carolina (S. N. Jeffers, unpublished data). Many other species of Phytophthora and genera of fungi also have been found in irrigation water associated with other crops $(20,28,29,36)$.

Adequate specificity of the PCR assay reported here was evidenced by very few unspecific amplicons among a large number of diverse microorganisms. These microorganisms included major groups of Pythium, other water mold fungi, bacteria, and some important fungal pathogens, which were in addition to the 15 other species of Phytophthora. The species of Phytophthora tested represent the six morphological groups described by Waterhouse $(7,41)$ and all species that have been recovered from nursery irrigation water in the United States $(13,22,25,39)$. Among the species that did not react with the PN primers were three species on the same internal transcribed spacer (ITS) clade as $P$. nicotianae: $P$. pseudotsugae, $P$. phaseoli, and $P$. infestans (4). Nonreactive species also included $P$. capsici, $P$. citrophthora, $P$. heveae, and $P$. tropicalis, which are in the same morphological group (II) as $P$. nicotianae (41).

The amplification of DNA from the isolates of $P$. cambivora (1D2) and P. cactorum (W.097) should not present a problem. The population of $P$. cambivora in irrigation water is very limited. This species was isolated only once during monthly assays of irrigation runoff and irrigation water at two commercial nurseries and quarterly assays at four other nurseries in Virginia over the past 2 years (C. X. Hong, unpublished data). It also was recovered from 1 of 31 irrigation sources surveyed for occurrence of Phytophthora spp. in British Columbia, Canada (28) and from surface water irrigation sources in California (29). Isolation of this species from runoff or irrigation water has not been documented anywhere else. The potential of this unspecific amplification of DNA from $P$. cambivora with the PN primers is small, and unspecific amplification can be identified by running the PCR products of water samples sided with a positive control on $3 \%$ Nusieve gels or DNA hybridization with the species-specific probe. The $P$. cactorum isolate (W.097) was reexamined morphologically and also using a single strand conformational polymorphism (SSCP) analysis ( $\mathrm{P}$. Kong, unpublished data). This isolate has the typical morphological characters $(7,41)$ and SSCP profile of $P$. cactorum. The cause of the amplification of DNA from this isolate remains unclear. Natural hybridization between $P$. nicotianae and $P$. cactorum has been reported (27) so isolate W.097 could be another natural hybrid between the two species.

The amplification of DNA from the one isolate of each of Pythium irregulare (P11), Alternaria porri (AP1), and a bacterium (SW1) also is not a major concern. The amplicons of P11 and AP1 were distinguished easily from the specific band (230 bp) for $P$. nicotianae. Both amplicons also had very weak signals even with $5 \mu \mathrm{l}$ of PCR products on $3 \%$ Nusieve gel so they may not be easily seen on regular gels. The amplicon of DNA from a bacterial isolate was a concern although it occurred only once in specificity tests. This amplicon had a strong signal with a size similar to the specific band; both were hard to differentiate on $1 \%$ agarose gels. However, this unspecific amplicon can be separated from the 
specific one by running $5 \mu \mathrm{l}$ of PCR products sided with a positive control on $3 \%$ Nusieve gel, as illustrated in Figure 1. In fact, this unspecific amplification was not observed for any naturally infested water sample from Virginia and South Carolina in 2001 and from Virginia in 2002 (data not shown). These PCR detection results were supported by the DNA hybridization. The bacterium of concern may not have existed, its population was low in these samples, or the majority of the bacterium cells may have passed through during the filtration process. These results indicate that use of the PCR assay alone without Southern blot hybridization probably is sufficient for detecting $P$. nicotianae in irrigation water samples. Nevertheless, the low risk of producing false positives can be assessed by testing a large number of irrigation water samples from different nurseries that grow a wide variety of host plants.

False positives have been a serious concern for detecting Phytophthora spp. in irrigation water with serological tests $(2,26,40)$. It also is a concern for other PCR protocols. For example, the PP primers had strong cross-reactivity with $P$. capsici and $P$. cryptogea (data not shown). The other $P$. nicotianae-specific primers that, like ours, also are derived from parAl sequences were evaluated with only isolates of Phytophthora spp. (21). A major concern about these primers is the risk of cross reactivity with Pythium spp. Many species of Pythium have genes that may be homologous to the elicitin gene of $P$. nicotianae $(10,32)$, and Pythium spp. can be abundant in irrigation water $(13,40)$ and grow rapidly on agar media (9).

The PCR assay also has sufficient sensitivity for detection of $P$. nicotianae in irrigation water and produced minimal false negatives, a serious concern for other methods. Detection of a low number of propagules can be a problem for standard isolation methods. This became more obvious after the threshold number for propagules of $P$. nicotianae in irrigation water for annual vinca was established (14). Isolation methods detected Phytophthora spp. in irrigation water at a minimum of $33.3 \mathrm{CFU} /$ liter (ca. 333 spores per liter) (16), which is well above the level at which $P$. nicotianae is capable of causing disease (14). As a result, standard isolation methods are inadequate for detecting low levels of $P$. nicotianae. It is worthwhile noting that $P$. nicotianae caused severe foliage blight on annual vinca (Catharanthus roseus) in field plots at a Virginia nursery (15) where irrigation pond water samples were collected for this study. The field plots were established to demonstrate the significance of recycled irrigation water as a source of inoculum for Phytophthora diseases at ornamental crop nurseries. $P$. nicotianae was detected in irrigation pond water in September 2001 with the PCR assay but not by isolation, while an outbreak of foliage blight occurred on annual vinca irrigated with the same water (15).

Sensitivity of the PCR assay developed in this study was demonstrated by detection of $P$. nicotianae in both artificially and naturally infested water samples. Zoospore PCR detected $P$. nicotianae at levels of 1 zoospore in SDW or 10 zoospores in filtered irrigation water. Similarly, the PCR assay using raw DNA extract detected the pathogen in artificially infested irrigation water filtrate at levels of 20 to 200 zoospores per liter, depending on the zoospore collecting method. More importantly, the PCR assay detected the pathogen in more samples of naturally infested runoff water and irrigation water from Virginia and South Carolina than the standard isolation method (seven versus two samples).

The sensitivity of the PCR assay can be further enhanced by use of concentrated DNA extracts. The assay appeared tolerant to the inhibitors that may have been in the extraction samples from irrigation runoff water and irrigation water. This tolerance allowed use of concentrated DNA extract from water samples for template amplification to increase detection sensitivity. Detection of $P$. nicotianae in the water sample collected from location G2 in South Carolina illustrated how using concentrated DNA extract can improve sensitivity of the PCR assay. This detection result implies that the sensitivity of the PCR assay can be enhanced at least five times by using concentrated DNA extracts, i.e., the assay can detect the pathogen in irrigation water at 4 to 40 zoospores per liter. The detection sensitivity of the PCR assay is between 80 and $800 \mathrm{fg} / \mu \mathrm{l}$. This detection threshold affects the utility of the PCR assay, but it is unlikely to be affected by the quality of DNA extracted from irrigation runoff water and irrigation pond water samples.

The PCR assay appeared equally sensitive to all five isolates of $P$. nicotianae tested. This suggests broad application of the assay across the host range and geographic distribution of this pathogen. Additional sensitivity tests with more isolates are warranted to further validate this applicability. In addition, one isolate of $P$. nicotianae from Hedera helix tested negative. It is interesting that this isolate has the same morphological characters and SSCP pattern as other isolates recovered from Hedera spp. that tested positive with the PN primers. This isolate deserves further examination.

The PCR assay with the PN primers was more sensitive than the PP primers. This could have been attributed partially to the different sizes of amplicons: $230 \mathrm{bp}$ for the PN primers and $950 \mathrm{bp}$ for the PP primers. In general, the smaller the size of the amplicon, the more efficient the replication will be. It also could have been due in part to the primers' tolerance to inhibitors in the raw DNA extract from irrigation water samples. This was evidenced by detection in the water sample from location CU in South Caro-
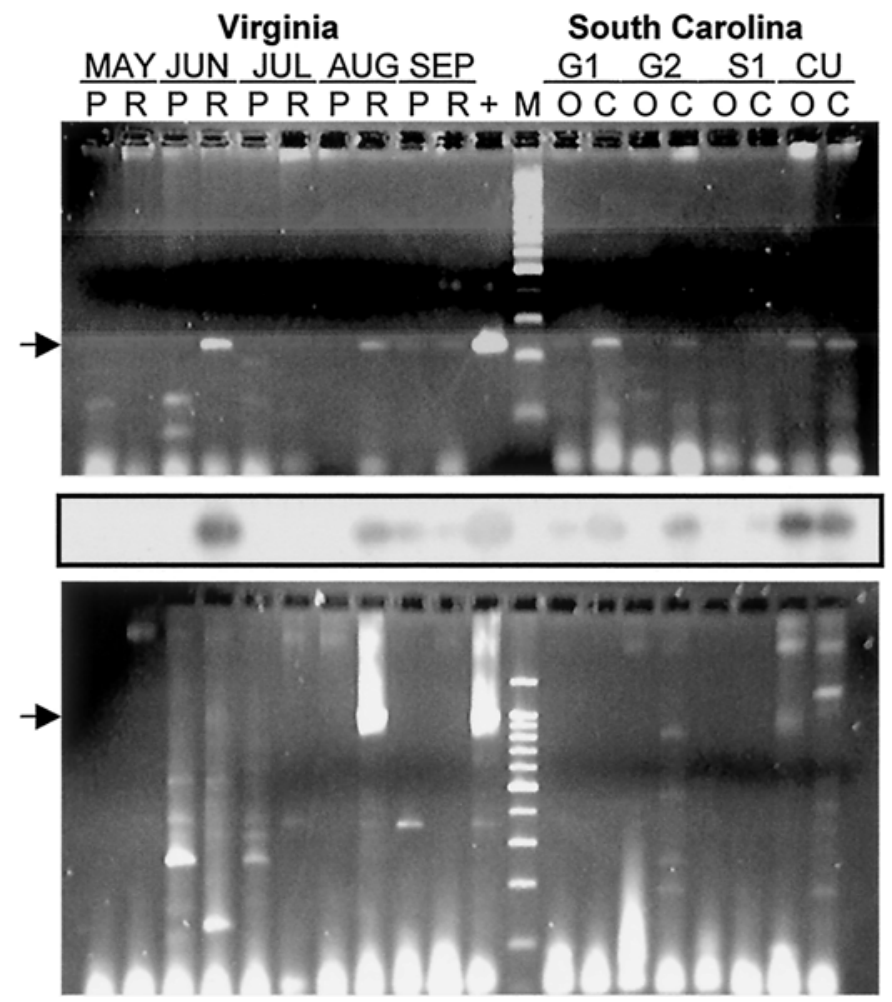

Fig. 6. Nusieve gel electrophoresis of polymerase chain reaction (PCR) products of DNA from irrigation water samples collected at a commercial nursery in Virginia from May to September 2001 (left) and at two commercial nurseries ( $\mathrm{G}$ and $\mathrm{S}$ ) and a creek flowing through a landscape $(\mathrm{CU})$ in South Carolina in September 2001 (right). Aliquots of runoff water $(50 \mathrm{ml})$ or recycled irrigation water from a holding pond $(100 \mathrm{ml})$ were passed through Osmonics nylon membrane filters with $5-\mu \mathrm{m}$ pores to collect pathogen propagules prior to DNA extraction using the UltraClean Soil DNA kit. $\mathrm{P}=$ irrigation pond water and $\mathrm{R}=$ runoff water. The concentration of DNA used as templates for South Carolina samples: $\mathrm{O}=$ original DNA extract and $\mathrm{C}=5 \times$ concentrated DNA. $+=$ positive control with purified DNA of Phytophthora nicotianae and $\mathrm{M}=100$-bp DNA ladder. Arrows point to the specific bands for: top $=$ the Phytophthora nicotianae-specific primers $(\mathrm{PN})$ designed in this study; bottom $=$ the $P$. parasitica-specific primers reported by Ersek et al. (6). DNA hybridization of the PCR products with the parAl probe confirmed detection with the PN primers (middle). 
lina. PN and PP primers detected P. nicotianae with the original DNA extract, but only the PN primers detected it with the $5 \times$ concentrated one.

Development of this PCR assay has significant practical implications. Use of the assay can provide rapid and accurate detection of $P$. nicotianae in water samples at an adequate level of sensitivity, which will allow growers to make timely disease management decisions with confidence. The PCR assay also could be an effective research tool for studying the ecology of $P$. nicotianae and evaluating management strategies for diseases caused by this pathogen.

In spite of the demonstrated detection specificity and sensitivity, the PCR assay developed in this study must be used with care. Filtration is the preferred method for collecting zoospores from water samples because it can reduce the risk of false positive detection from cross reaction with bacteria, and possibly other microorganisms smaller than the 5- $\mu$ m pore size of the filter, that may be present in irrigation water. Also, samples testing negative with original DNA extract should be rerun with concentrated extracts to reduce the risk of false negatives. It also is advisable to include an internal control by adding well purified DNA of $P$. nicotianae to DNA extracted from irrigation runoff water and irrigation pond water samples when using the PCR assay for diagnosis. Customization of this assay for detection of the pathogen in plants and soil is underway. In the future, we plan to compare this PCR assay with other similar assays, including two nested PCR protocols reported recently $(12,17)$ using naturally infested water samples, and also to improve the quantitative capability of the assay.

\section{ACKNOWLEDGMENTS}

This research was supported in part by a USDA/Southern Region IPM Special Grants Program grant 00-34103-9052. We thank J. Adaskaveg at the University of California, Riverside; D. M. Benson at North Carolina State University, Raleigh; M. E. Gallegly at West Virginia University, Morgantown; M. A. Hansen at Virginia Polytechnic Institute and State University, Blacksburg; G. W. Moorman at Pennsylvania State University, University Park; and S. L. von Broembsen at Oklahoma State University, Stillwater for providing isolates of species of Phytophthora and Pythium.

\section{LITERATURE CITED}

1. Ali-Shtayeh, M. S., and MacDonald, J. D. 1991. Occurrence of Phytophthora species in irrigation water in the Nablus area (West Bank of Jordan). Phytopathol. Mediterr. 30:143-150.

2. Ali-Shtayeh, M. S., MacDonald, J. D., and Kabashima, J. 1991. A method for using commercial ELISA tests to detect zoospores of Phytophthora and Pythium species in irrigation water. Plant Dis. 75:305-311.

3. Audy, P., Braat, C. E., Saindon, G., Huang, H. C., and Laroche, A. 1996. Rapid and sensitive PCR-based assay for concurrent detection of bacteria causing common and halo blights in bean seed. Phytopathology 86:361-366.

4. Cooke, D. E. L., Drebth, A., Duncan, J. M., Wagels, G., and Brasier, C. M. 2000. A molecular phylogeny of Phytophthora and related Oomycetes. Fungal Genet. Biol. 30:17-32.

5. Dukes, P. D., Jenkins, S. F., Jr., and Thompson, S. S., Jr. 1977. Detection and some observations of Phytophthora parasitica var. nicotianae in ponds used for irrigation of tobacco. Tob. Sci. 21:97-100.

6. Ersek, T., Schoelz, J. E., and English, J. T. 1994. PCR amplification of species-specific DNA sequences can distinguish among Phytophthora species. Appl. Environ. Microbiol. 60:2616-2621.

7. Erwin, D. C., and Ribeiro, O. K. 1996. Phytophthora Diseases Worldwide. The American Phytopathological Society, St. Paul, MN.

8. Faggian, R., Bulman, S. R., Lawrie, A. C., and Porter, I. J. 1999. Specific polymerase chain reaction primers for the detection of Plasmodiophora brassicae in soil and water. Phytopathology 89:392-397.

9. Ferguson, A. J., and Jeffers, S. N. 1999. Detecting multiple species of Phytophthora in container mixes from ornamental crop nurseries. Plant Dis. 83:1129-1136.

10. Gayler, K. R., Popa, K. M., Maksel, D. M., Ebert, D. L., and Grant, B. R. 1997. The distribution of elcitin-like gene sequences in relation to elicitin protein secretion within the class Oomycetes. Mol. Plant Pathol.
On-line publication bspp.org.uk/mppol/1997/0623 gayler.

11. Goodwin, P. H., Kirkpatrick, B. C., and Duniway, J. M. 1989. Cloned DNA probes for identification of Phytophthora parasitica. Phytopathology 79:716-721.

12. Grote, D., Olmos, A., Kofoet, A., Tuset, J. J., Bertolini, E., and Cambra, M. 2002. Specific and sensitive detection of Phytophthora nicotianae by simple and nested PCR. Eur. J. Plant Pathol. 108:197-207.

13. Hong, C. X., Bush, E. A., Richardson, P. A., and Stromberg, E. L. 2002. The major deterrent to recycling irrigation water in nursery and greenhouse operations despite the lack of alternatives for limiting nonpoint source pollution. Pages 72-77 in: Proc. Va. Water Res. Symp. 2001. Virginia Polytechnic Institute and State University, Blacksburg.

14. Hong, C. X., and Epelman, G. 2000. Development of Phytophthora blight of annual vinca irrigated with contaminated water. Proc. Southern Nursery Assoc. Res. Conf. 45:233-235.

15. Hong, C. X., Kong, P., and Richardson, P. A. 2002. Epidemiological significance of Phytophthora species present in recycled irrigation water to ornamental production. (Abstr.) Phytopathology 92(suppl.):S143.

16. Hong, C. X., Richardson, P. A., and Kong, P. 2002. Filter membranes as tools for monitoring pythiaceous species in irrigation water. Phytopathology 92:610-616.

17. Ippolito, A., Schena, L., and Nigro, F. 2002. Detection of Phytophthora nicotianae and P. citrophthora in citrus roots and soils by nested PCR. Eur. J. Plant Pathol. 108:855-868.

18. James, D. 1999. A simple and reliable protocol for detection of apple stem growing virus by RT-PCR and in a multiplex PCR assay. J. Virol. Methods 83:1-9.

19. Kamoun, S., Klucher, K., Coffey, M., and Tyler, B. 1993. A gene encoding a host-specific elicitor protein of Phyophthora parasitica. Mol. Plant-Microbe Interact. 6:573-581.

20. Klotz, L. J., Wong, P. P., and DeWolfe, T. A. 1959. Survey of irrigation water for the presence of Phytophthora spp. pathogenic to citrus. Plant Dis. Rep. 43:830-832.

21. Lacourt, I., and Duncan, J. M. 1997. Specific detection of Phytophthora nicotianae using the polymerase chain reaction and primers based on the DNA sequence of its elicitin gene ParA1. Eur. J. Plant Pathol. 103:73-83.

22. Lauderdale, C. C. and Jones, R. K. 1997. Monitoring irrigation ponds for Phytophthora spp. Proc. Southern Nursery Assoc. Res. Conf. 42:225226.

23. Levesque, C. A., Harlton, C. E., and de Cock, A. W. A. M. 1998. Identification of some oomycetes by reverse dot blot hybridization. Phytopathology 88:213-222.

24. Levesque, C. A., Vrain, T. C., and De Boer, S. H. 1994. Development of a species-specific probe for Pythium ultimum using amplified ribosomal DNA. Phytopathology 84:474-478.

25. MacDonald, J. D., Ali-Shtayeh, M. S., Kabashima, J., and Stites, J. 1994. Occurrence of Phytophthora species in recirculated nursery irrigation effluents. Plant Dis. 78:607-611.

26. MacDonald, J. D., Stites, J., and Kabashima, J. 1990. Comparison of serological and culture plate methods for detecting species of Phytophthora, Pythium, and Rhizoctonia in ornamental plants. Plant Dis. 74:655659.

27. Man in`t Veld, W. A., Veen-baas-Rijks, W. J., Ilieva, E., de Cock, A. W. A. M., Bonants, P. J. M., and Pieters, R. 1998. Natural hybrids of Phytophthora nicotianae and Phytophthora cactorum demonstrated by isozyme analysis and random amplified polymorphic DNA. Phytopathology 88:922-929.

28. McIntosh, D. L. 1966. The occurrence of Phytophthora spp. in irrigation systems in British Columbia. Can. J. Bot. 44:1591-1594.

29. Mircetich, S. M., Browne, G. T., Krueger, W., and Scheader, W. 1985. Phytophthora spp. isolated from surface-water irrigation sources in California. (Abstr.) Phytopathology 75:1346-1347.

30. Moricca, S., Ragazzi, A., Kasuga, T., and Mitchelson, K. R. 1998. Detection of Fusarium oxysporum f. sp. vasinfectum in cotton tissue by polymerase chain reaction. Plant Pathol. 47:486-494.

31. Oudemans, P. V. 1999. Phytophthora species associated with cranberry root rot and surface irrigation water in New Jersey. Plant Dis. 83:251258.

32. Panabières, F., Michel, P., Allasia, V., and Cardin, L. 1997. Characterization of border species among Pythiaceae: Several Pythium isolates produce elicitins, typical proteins from Phytophthora spp. Mycol. Res. 101:1459-1468.

33. Picard, C., Ponsonnet, C., Paget, E., and Nesme, X. 1992. Detection and enumeration of bacteria in soil by direct DNA extraction and polymerase chain reaction. Appl. Environ. Microbiol. 58:2717-2722.

34. Pittis, J. E., and Colhoun, J. 1984. Isolation and identification of pythiaceous fungi from irrigation water and their pathogenicity to Antirrhinum, tomato, and Chamaecyparis lawsoniana. Phytopathol. Z. 110:301-318. 
35. Schubert, R., Bahnweg, G., Necheatal, J., Jung, T., Cooke, D. E. L., Duncan, J. M., Muller-Starck, G., Langebartels, C., Sandermann, H., Jr., and Oswald, W. 1999. Detection and quantification of Phytophthora species which are associated with root-rot diseases in European deciduous forests by species-specific polymerase chain reaction. Eur. J. For. Pathol. 29:171-188.

36. Shokes, F. M., and McCarter, S. M. 1979. Occurrence, dissemination, and survival of plant pathogens in surface irrigation ponds in southern Georgia. Phytopathology 69:510-516.

37. Thomas, S. B. L., White, J., and Taylor, J. W. 1993. Detection of Phytophthora species by oligonucleotide hybridization to amplified ribosomal DNA spacers. Phytopathology 83:177-181.

38. Thomson, S. V., and Allen, R. M. 1974. Occurrence of Phytophthora species and other potential plant pathogens in recycled irrigation water. Plant Dis. Rep. 58:945-949.

39. von Broembsen, S. L., and Wilson, S. K. 1998. Occurrence of Phytophthora spp. in nursery runoff and recycled irrigation water. (Abstr.) Phytopathology 88(suppl.):S92.

40. Wakeham, A. J., Pettitt, T. R., and White, J. G. 1997. A novel method for detection of viable zoospores of Pythium in irrigation water. Ann. Appl. Biol. 131:427-435.

41. Waterhouse, G. M. 1963. Key to the Species of Phytophthora de Bary. Mycol. Paper No. 92. Commonwealth Mycological Institute, Kew, UK.

42. Whiteside, J. O., and Oswalt, T. W. 1973. An unusual brown rot outbreak in a Florida citrus grove following sprinkler irrigation with Phytophthora-infested water. Plant Dis. Rep. 57:391-393. 